\title{
Upaya Meningkatkan Perhatian Anak Melalui Metode Bercerita dengan Media Boneka Tangan pada Anak Kelompok B TK Nurul Ibadah Kota Jambi
}

\begin{abstract}
Rosma Wati ${ }^{1}$
Abstrak: Penelitian ini bertujuan untuk meningkatkan perhatian anak pada saat pembelajaran kegiatan bercerita melalui metode bercerita dengan media boneka tangan.Alasan pemilihan media boneka tangan karena memiliki bentuk yang unik, corak dan motif yang beragam sehingga dapat menarik perhatian anak. Penelitian ini merupakan penelitian tindakan kelas kolaboratif menggunakan Model Kemmis dan Taggart tahun 1990. Subyek dalam penelitian ini adalah anak Kelompok B TK Nurul Ibadah Tahun Ajaran 2015/2016 yang berjumlah 15 anak terdiri dari 9 lakilaki dan 6 perempuan. Metode pengumpulan data dilakukan dengan observasi dan dokumentasi. Instrumen yang digunakan berupa lembar observasi. Teknik analisis data yang digunakanadalah deskriptif kuantitatif. Perhatian anak pada saat pembelajaran kegiatan bercerita dapat ditingkatkan melalui metode bercerita dengan media boneka tangan dengan langkah-langkah (1) guru mengkondisikan anak, (2) guru memberitahu judul cerita yang akan dibacakan, (3)guru memperkenalkan boneka tangan sesuai tokoh dalam cerita (4) guru menceritakan isi cerita, (5) pada bagian akhir guru memberikan pertanyaan kepada anak untuk mengetahui ingatan dan pemahaman anak terhadap cerita yang dibacakan. Perhatian anak mengalami peningkatan setiap siklusnya. Pada pra tindakan perhatian anak dengan kriteria perhatian baik hanya sebesar $13.33 \%$ ( 2 anak). Setelah adanya tindakan pada Siklus I meningkat mencapai $60 \%$ (9 anak), dan pada Siklus II perhatian anak meningkat kembali hingga 93.33\% (14 anak).
\end{abstract}

Kata kunci: perhatian, metode bercerita, media boneka tangan, anak tamankanak-kanak

Abstract: This study aims to increase the attention of children during the learning of storytelling activities through the method of telling stories with hand puppet media. The reason for the selection of hand puppet media is because it has a unique shape, patterns and motifs that attract children's attention. This study is a collaborative classroom action research using the Kemmis and Taggart Model in 1990. The subjects in this study were the Group B children of Nurul Ibadah Kindergarten 2015/2016 Academic Year, totaling 15 children consisting of 9 men and 6 women. The method of data collection is done by observation and documentation. The instrument used was an observation sheet. The data analysis technique used is quantitative descriptive. Children's attention when learning storytelling activities can be increased through the method of telling stories with hand puppet media with steps (1) the teacher conditions the child, (2) the teacher tells the story title to be read, (3) the teacher introduces the puppet according to the characters in the story (4) the teacher tells the contents of the story, (5) at the end of the teacher gives a question to the child to know the child's memory and understanding of the story being read. Children's attention increases every cycle. In preaction the attention of children with the criteria of good attention was only $13.33 \%$ ( 2 children). After the action in Cycle I increased to 60\% (9 children), and in Cycle II the attention of children increased again to 93.33\% (14 children).

Keywords: attention, storytelling method, hand puppet media, childcare

\section{PENDAHULUAN}

Pendidikan merupakan hal penting untuk diperhatikan. Pendidikan akanmembuat wawasan pengetahuan menjadi terbuka dan bertambah sehingga terciptasumber daya manusia yang berkualitas. Bangsa Indonesia sendiri pada saat inisedang berupaya untuk menyiapkan sumber daya manusia yang berkualitas dalam memasuki era globalisasi yang penuh dengan tantangan. Upaya tersebut tidak bisa dilakukan secara instant melainkan harus bertahap. Tahap awal yang paling baik adalah dengan menanamkan pendidikan sejak anak usia dini.Pendidikan anak usia dini (PAUD) merupakan pendidikan yang palingrendah tingkatannya. Meskipun demikian PAUD memiliki makna yang palingtinggi dari satuansatuan pendidikan lainnya karena akan melandasi pendidikandasar, pendidikan menengah, dan pendidikan tinggi. Undang-undang nomor 20tahun 2003 tentang Sistem Pendidikan Nasional menyebutkan bahwa:"Pendidikan Anak Usia Dini (PAUD) merupakan suatu upaya pembinaan yang ditujukan kepada

${ }^{1}$ Guru Paud Taman Kanak-Kanak Nurul Ibadah Kota Jambi 
anak sejak lahir sampai dengan usia enam tahun yang dilakukan melalui pemberian rangsangan pendidikan untuk membantu pertumbuhan dan perkembangan jasmani dan rohani agar anak memiliki kesiapan dalam memasuki pendidikan lebih lanjut."

Anak usia dini pada rentang usia 0-6 tahun merupakan masa golden age yang penting untuk mendapatkan perhatian. Golden age adalah masa dimanaseluruh aspek perkembangan anak sedang berkembang dan terjadi pematangan fungsi fisik dan psikis yangsiap merespons berbagairangsangan darilingkungannya. Oleh karena itu peran orang-orang disekitar anak memberikan kontribusi yang besar terhadap perkembangan anak yang optimal.Guru merupakan orang terdekat anak di sekolah. Pada saat menciptakan pembelajaran guna menstimulasi perkembangan anak yang optimal guru sebaiknya memahami karakteristik anak usia dini.

Sofia Hartati (2005: 8) mengemukakan bahwa salah satu karakteristik anak usia dini adalah anak memiliki daya konsentrasi yang pendek. Dengan demikian pembelajaran yang diciptakan oleh guru harus menarik perhatian anak.Perhatian anak terhadap pembelajaran merupakan suatu hal penting yang harus diperhatikan oleh guru karena keberhasilan pembelajaran ditentukan oleh seberapa besar perhatian anak terhadap pembelajaran yang disampaikan. Anak yang memiliki perhatian terpusat maka hasil belajarnya akan baik. Hal tersebut sesuai dengan pendapat Slameto (2003: 56) yang menyebutkan perhatian merupakan faktor intern yang mempengaruhi belajar individu dan apabila tidak terpenuhi maka akan menghambat keberhasilan belajar anak.

Sumadi Suryabrata (2004: 14) menyebutkan perhatian adalah banyak sedikitnya kesadaran yang menyertai suatu aktivitas yang dilakukan. Suatu objek haruslah menarik agar mendapat perhatian bagi yang melihat. Hasil belajar yang baik dapat diperoleh apabila anak mempunyai perhatian terhadap bahan yang dipelajarinya, jika bahan pelajaran yang dipelajari tidak menarik maka akan timbul kebosanan.Perhatian anak dapat ditingkatkan melalui strategi pembelajaran yang menarik. Salah satu strategi pembelajaran yang dapat digunakan adalah metodebercerita.

Muhammad Fadlillah (2014: 172) menyebutkan metode bercerita adalah metode yang mengisahkan suatu peristiwa atau kejadian kepada anak. Kejadian atau peristiwa tersebut disampaikan kepada anak melalui tutur kata, ungkapan, dan mimik wajah yang unik. Mendengarkan cerita untuk anak Taman Kanakkanak (TK) merupakan hal yang mengasyikkan. Hal tersebut dikarenakan dalam cerita disampaikan berbagai macam kisah menarik yang berkaitan dengan materi pembelajaran.Moeslichatoen (2004: 140) mengemukakan melalui metode bercerita anak dilatih untuk menjadi pendengar yang kritis dan kreatif. Pendengar yang kritis mampu menemukan kesesuaian antara yang telah didengar dengan yang telah dipahami. Sedangkan pendengar yang kreatif mampu menemukan pemikiran-pemikiran baru dari apa yang telah didengarnya. Manfaat lain yang dapat dirasakan dari metode ini adalah dapat melatih konsentrasi dan daya tangkap serta membantu perkembangan imajinasi anak. Pada saat menggunakan metode bercerita ada yang disertai dengan alat peraga maupun alat peraga.

Anak taman kanak-kanak lebih menyukai mendengarkan cerita dengan alat peraga karena dengan alat peraga anak menjadi lebih tertarik untuk memperhatikan. Hal tersebut sesuai dengan pernyataan Yasmin dalam Syhinta Yulia (2012: 3) bahwa:

"manfaat alat peraga diantaranya adalah menyampaikan suatu konsep dengan bentuk yang baru, mempertahankan konsentrasi, mengajar dengan lebih cepat, mengatasi masalah keterbatasan waktu, mengatasi masalah keterbatasan tempat, mengatasi masalah keterbatasan bahasa, membangkitkan emosi manusia dan menyampaikan suatu konsep dengan bentuk yang baru".Adanya alat peraga dapat membuat anak memiliki perhatian yang lebih dan mempertahankannya sampai guru selesai bercerita.

Tadkiroatun Musfiroh (2005: 141) menyebutkan alat peraga dalam bercerita yang dapat digunakan berupa buku, gambar, boneka, dan gambar gerak. Firdaus Muttaqin (2013) menggunakan boneka tangan untuk meningkatkan keterampilan bercerita.Peneliti melakukan observasi pada hari Senin, 12 Januari 2015 dan Kamis, 15 Januari 2015 pada anak kelompok B TK Nurul Ibadah . Observasi dilakukan pada saat pembelajaran kegiatan bercerita, yaitu ketika guru membacakan cerita. Pada saat guru membacakan cerita perhatian anak berlum optimal. Terlihat anak belum tertarik dan fokus pada cerita yang dibacakan. Pada saat itu peneliti hanya melihat 3 anak di dalam kelas yang berisi 15 anak yang terlihat mendengarkan cerita yang dibacakan guru. 
Pada bagian akhir ketika guru menanyakan kembali cerita yang telah dibacakan ternyata sebanyak 11 anak tidak ada yang mengangkat tangan untuk menceritakan kembali cerita yang telah dibacakan. Pada saat yang sama peneliti juga melakukan wawancara dengan guru kelas. Berdasarkan wawancara dengan guru kelas, guru belum melakukan upaya untuk meningkatkan perhatian anak pada saat pembelajaran kegiatan bercerita. Selain itu guru juga belum mengembangkan media dalam penyampaian cerita.

Melihat kenyataan di atas perlu dilakukan suatu tindakan baru untuk meningkatkan perhatian anak pada saat pembelajaran kegiatan bercerita dengan menggunakan media yang menarik pada saat guru bercerita. Salah satu media yang dapat digunakan untuk menarik perhatian anak pada saat pembelajaran kegiatan bercerita adalah dengan menggunakan media boneka tangan.Ari Siswanti dkk. (2013: 3) mengemukakan boneka tangan adalah tiruan dalam bentuk manusia, hewan maupun bentuk lainnya yang ukurannya disesuaikan dengan ukuran tangan dengan berbagai corak dan motif.

Menurut Sudjana dalam Klara (tt: 2) boneka tangan adalah boneka yang digerakkan oleh tangan. Boneka tangan ini dapat dibuat sendiri sesuai dengan karakter tokoh yang diinginkan ataupun dapat di beli di toko. Cara penggunaannya pun mudah yaitu tangan masuk ke dalam boneka kemudian digerakkan. Boneka tangan sengaja dipilih karena memiliki bentuk yang menarik dan unik serta memiliki corak dan motif yang beragam sehingga menimbulkan rasa ketertarikan pada anak dan boneka tangan ini juga belum pernah digunakan oleh guru.Berdasarkan permasalahan yang telah disampaikan di atas maka peneliti mengadakan penelitian tentang "Upaya Meningkatkan Perhatian Anak Melalui Metode Bercerita dengan Media Boneka Tangan Pada Anak Kelompok B TK Nurul Ibadah Tahun Pelajaran 2015/2016 ”.Tujuan dari penelitian ini adalah untuk meningkatkan perhatian anak melalui metode bercerita dengan media boneka tangan, sehingga dalam penelitian ini dapat menambah wawasan guru dalam pembelajaran kegiatan bercerita menggunakan media agar menarik perhatian anak.Anak lebih senang saat mendengarkan cerita karena disertai dengan media khususnya boneka tangan.

Perhatian anak usia dini adalah pemusatan keaktifan jiwa anak yang diarahkan untuk memperhatikan obyek secara penuh pada suatu waktu tertentu dalam pembelajaran. Perhatian anak dalam penelitian ini dilihat pada saat guru bercerita, dan yang menjadi penilaian meliputi konsentrasi, ingatan, dan pemahaman.Metode bercerita adalah metode yang mengisahkan suatu peristiwa kepada anak untuk memberikan pengalaman belajar bagi anak TK dengan membawakan cerita kepada anak secara lisan.Boneka tangan adalah tiruan dalam bentuk manusia, hewan maupun bentuk lainnya yang ukurannya disesuaikan dengan ukuran tangan dengan berbagai corak dan motif. Pada penelitian ini upaya meningkatkan perhatian anak melalui metode bercerita dengan media boneka tangan merupakan suatu upaya untuk meningkatkan pemusatan keaktifan jiwa anak yang diarahkan untuk memperhatikan obyek secara penuh pada pembelajaran kegiatan bercerita.

\section{Landasan Teori}

Perhatian merupakan salah satu faktor yang dapat mempengaruhi hasil belajar anak. Gazali dalam Slameto (2003: 56) mengemukakan perhatian adalah keaktifan jiwa yang dipertinggi semata-mata tertuju kepada suatu obyek atau sekumpulan obyek. Abu Ahmadi (2003: 145) mengemukakan perhatian adalah keaktifan jiwa yang diarahkan kepada suatu objek, baik di dalam maupun di luar dirinya. Sumadi Suryabrata (2004: 14) mengemukakan perhatian adalah banyak sedikitnya kesadaran yang menyertai sesuatu aktivitas yang dilakukan. Senada dengan pendapat di atas Bimo Walgito (2004: 98) menyebutkan perhatian merupakan pemusatan atau konsentrasi dari seluruh aktivitas individu yang ditujukkan kepada suatu obyek atau sekumpulan obyek. Berdasarkan beberapa pengertian perhatian yang diuraikan oleh beberapa ahli di atas maka dapat disimpulkan perhatian adalah pemusatan keaktifan jiwa yang diarahkan untuk memperhatikan obyek secara penuh pada suatu waktu tertentu.

Pada penelitian ini perhatian yang dimaksud adalah perhatian anak usia dini. Perhatian anak usia dini terhadap pembelajaran akan menentukan hasil belajar anak. Jadi perhatian anak usia dini dapat diartikan sebagai pemusatan keaktifan jiwa anak yang diarahkan untuk memperhatikan obyek secara penuh pada suatu waktu tertentu dalam pembelajaran. Tingkat perhatian anak untuk memperhatikan obyek bergantung pada usia.Menurut Olivia dalam Tsaniy Nur Farhani (2012: 4) anak usia 1-2 tahun memiliki rentang perhatian sekitar 5 menit, usia 3-4 tahun 10 menit, dan usia di atas 5 tahun sekitar 20 menit. 
Menurut Widodo Judarwanto (2011: 2) rata-rata rentang atensi pada usia 2 tahun selama 7 menit, usia 3 tahun selama 9 menit, usia 4 tahun selama 12 menit, usia 5 tahun selama 14 menit.Dalam penelitian ini subyek penelitian adalah anak usia 4-5 tahun. Jadi rentang perhatian anak usia 4-5 tahun adalah sekitar 1014 menit.Bimo Walgito (2004: 100) menyebutkan perhatian ada bermacam-macam, sesuai dari segi yang ditinjau, yaitu:Ditinjau dari segi timbulnya perhatian perhatian spontan, yaitu perhatian yang timbul dengan sendirinya secara spontan. Perhatian ini erat hubungannya dengan minat individu terhadap suatu obyek. Perhatian anak usia dini terhadap pembelajaran merupakan hal penting yang perlu diperhatikan dan ditingkatkan oleh guru. Perhatian anak terhadap pembelajaran perlu ditingkatkan karena keberhasilan pembelajaran ditentukan oleh seberapa besar perhatian anak terhadap pembelajaran yang disampaikan. Selain itu anak yang memiliki perhatian terpusat maka hasil belajarnya akan baik.

\section{METODE PENELITIAN \\ Jenis Penelitian}

Jenis penelitian ini merupakan Penelitian Tindakan Kelas (PTK). Menurut Wina Sanjaya (2011: 26) penelitian tindakan kelas adalah proses pengkajian masalah pembelajaran didalam kelas melalui refleksi diri dalam upaya untuk memecahkan masalah tersebut dengan cara melakukan berbagai tindakan yang terencana dalam situasi nyata serta menganalisis setiap pengaruh dari perlakuan tersebut. Pemilihan jenis penelitian tindakan kelas ini memiliki beberapa alasan yang dapat diuraikan sebagai berikut: (1) masalah yang dihadapi adalah masalah yang timbul dalam proses pembelajaran, (2) tidak menganggu jalannya pembelajaran sesuai dengan kompetensi yang diajarkan, (3) ingin melihat adanya peningkatan perhatian anak.

Penelitian Tindakan Kelas ini menggunakan model kolaborasi yang mengutamakan kerjasama antara peneliti dan guru.Peneliti bekerjasama dengan guru Kelompok B di TK Nurul Ibadah mulai dari merencanakan, melaksanakan tindakan, mengobservasi dan merefleksi tindakan. Peneliti senantiasa terlibat langsung dalam prosespenelitian dari awal sampai akhir penelitian dan peneliti juga bertugas memantau, mencatat, mengumpulkan data, menganalisis data serta melaporkan hasil penelitian dengan dibantu oleh kolaborator.

\section{Subyek dan Obyek Penelitian}

Muhammad Idrus (2009: 91) menyebutkan subyek penelitian adalah individu, benda atau organisme yang dijadikan sumber informasi yang dibutuhkan dalam pengumpulan data penelitian. Subyek penelitian dalam penelitian ini adalah anak Kelompok B di TK Nurul Ibadah yang berusia 4-5 tahun. Jumlah anak dalam Kelompok B ada 15 anak yang terdiri dari 9 laki-laki dan 6 perempuan. Obyek penelitian dalam penelitian ini adalah perhatian anak.

\section{Lokasi, Setting dan Waktu Penelitian}

Penelitian ini dilaksanakan di TK Nurul Ibadah.Setting penelitian dalam penelitian ini adalah di dalam kelas. Setting didalam kelas dalam lingkup sekolah ini dimaksudkan untuk mempermudah pelaksanaan tindakan yang akan dilakukan.

\section{Desain Penelitian}

Model penelitian yang dipilih dalam penelitian ini adalah model Kemmis dan Taggart tahun 1990. Wijaya Kusumah dan Dedi Dwitagama (2011: 20-21) menyatakan bahwa model penelitian Kemmis dan Taggart pada hakikatnya berupa perangkat-perangkat atau untaian-untaian dengan satu perangkat terdiri dari perencanaan (planning), tindakan (action) sekaligus pengamatan (observe), danrefleksi(reflection).

\section{Rencana Penelitian}

Penelitian ini dilakukan dalam tahapan yang berupa siklus yang tiap siklusnya terdiri dari tiga kali pertemuan. Apabila pada Siklus I kriteria keberhasilan belum tercapai maka dilanjutkan siklus selanjutnya sampai peneliti dan guru merasa puas dengan hasil yang didapat dan sesuai dengan kriteria keberhasilan yang ditetapkan. 


\section{Metode Pengumpulan Data \\ Metode Pengamatan}

Wina Sanjaya (2011: 86) mengemukakan bahwa observasi merupakan teknik mengumpulkan data dengan cara mengamati setiap kejadian yang sedang berlangsung dan mencatatnya dengan alat observasi tentang hal-hal yang akan diamati atau diteliti. Pada penelitian ini pengamatan dilakukan untuk mengetahui dan mengamati subjek penelitian secara bertahap dan untuk mengetahui seberapa jauh tingkat perhatian anak dalam mengikuti pembelajaran kegiatan bercerita melalui metode bercerita dengan media boneka tangan.

Subyek penelitian yang diobservasi yaitu anak Kelompok B di TK Nurul Ibadah. Data observasi dalam penelitian ini berupa lembar skoring yang berisi tentang kisi-kisi perhatian anak yang meliputi konsentrasi, ingatan, dan pemahaman.

\section{Metode Dokumentasi}

Dokumentasi digunakan untuk memperkuat data yang diperoleh dalam observasi. Pada penelitian ini peneliti akan mengambil beberapa dokumen dari TK Nurul Ibadah meliputi RKH, foto media pembelajaran yaitu boneka tangan, dan foto anak pada saat pembelajaran. RKH digunakan sebagai tanda bukti rencana proses pembelajaran yang dilakukan. Foto media digunakan sebagai bukti media yang digunakan dalam proses pembelajaran kegiatan bercerita untuk meningkatkan perhatian anak dangambar berupa foto berfungsi untuk menggambarkan secara nyata aktivitas anak pada pembelajaran kegiatan bercerita.

\section{Instrumen penelitian}

Nurul Zuriah (2005: 168) mengemukakan Instrumen penelitian adalah alat bantu bagi peneliti dalam mengumpulkan data. Instrumen yang digunakan dalam penelitian ini adalah:

1. Lembar Observasi

2. Dokumentasi

\section{Metode Analisis Data}

Teknik analisis data yang digunakan pada penelitian ini adalah teknik analisis data deskriptif kuantitatif. Data yang dianalisis berupa data hasil check listmengenai perhatian anak pada saat pembelajaran kegiatan bercerita. Data yangtelah diperoleh kemudian dikumpulkan dan di analisis.Selanjutnya rumus yang digunakan untuk menghitung rata-rata persentase adalah sebagai berikut:

$$
\mathrm{P}=\underline{\mathrm{F}} \times 100 \%
$$

\section{Keterangan:}

$\mathrm{P} \quad=$ Angka Persentase

$\mathrm{F} \quad=$ Frekuensi yang dicari persentasenya

$\mathrm{N} \quad=$ Number of Case (jumlah frekuensi atau banyaknya individu) Anas

Sudjiono (2008: 43).

\section{HASIL DAN PEMBAHASAN \\ Deskripsi Kondisi Awal Sebelum Pelaksanaan PTK}

Hasil yang didapat berdasarkan pengumpulan data observasi diperoleh gambaran tentang perhatian anak dalam mengikuti pembelajaran kegiatan bercerita pada Kelompok B TK Nurul Ibadah yang diperoleh dari 15 anak. Berdasarkan data hasil observasi diperoleh perhatian anak dengan kriteria baik dalam mengikuti pembelajaran kegiatan bercerita masih kurang. Hal tersebut dapat dilihat dari anak yang belum tertarik dan fokus pada cerita yang dibacakan guru. Selain itu pada saat guru menanyakan kembali cerita yang telah dibacakan sebagian besar tidak ada yang mengangkat tangan untuk menceritakan kembali cerita yang telah dibacakan. Kondisi perhatian anak pra tindakan dapat dapat dilihat pada Tabel 1. 
Tabel 1.

Rekapitulasi Kondisi Perhatian Anak Pra Tindakan

\begin{tabular}{cccc}
\hline No & Skor & Kriteria & Persentase \\
\hline 1 & $>6$ & Baik & $13.33 \%(2$ anak $)$ \\
2 & $5-6$ & Cukup & $20 \%(3$ anak $)$ \\
3 & $<5$ & Kurang & $66.67 \%(10$ anak $)$ \\
& & & $100 \%$ \\
\hline
\end{tabular}

Pada tabel di atas dapat diketahui bahwa sebagian besar perhatian anak berada pada kriteria perhatian kurang. Dari 15 anak yang menunjukkan perhatian dengan kriteria perhatian baik hanya sebesar $13.33 \%(2$ anak), anak yang menunjukkan perhatian dengan kriteria perhatian cukup sebesar 20\% (3 anak), dan sisanya menunjukkan perhatian dengan kriteria perhatian kurang sebesar 66.67\% (10 anak). Data pada tabel hasil perhatian anak pra tindakan di atas dapat diperjelas melalui grafik pada Gambar 3.

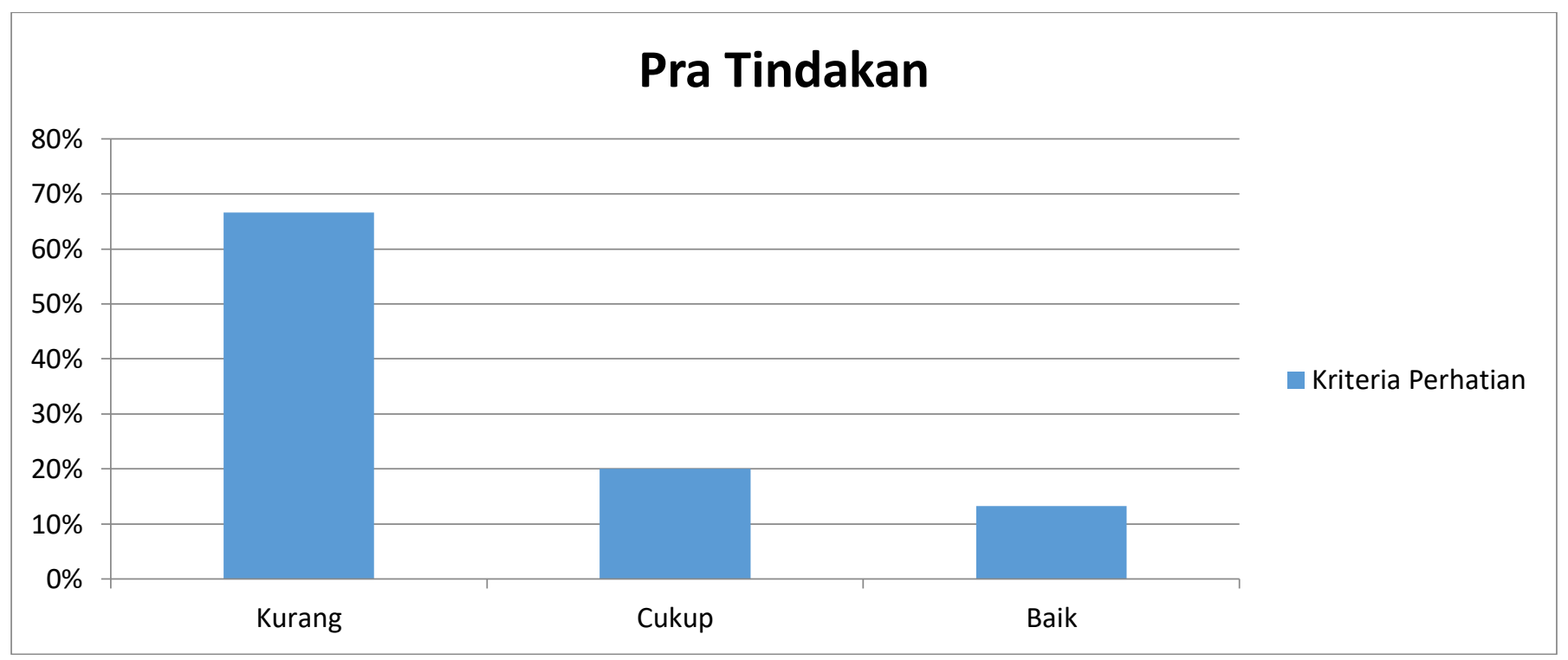

Gambar 1.

Grafik Persentase Perhatian Anak Pra Tindakan

\section{Siklus I}

Pengamatan dilakukan bersamaan dengan berlangsungnya tindakan. Pengamatan yang dilakukan selama kegiatan bercerita meliputi:(1) konsentrasi, (2) ingatan (memory), dan (3) pemahaman.Berdasarkan pengamatan yang dilakukan pada Siklus I diperoleh rata-rata hasil yang dicapai selama tiga kali pertemuan dapat dilihat pada tabel 2:

Tabel 2.

Rekapitulasi Data Perhatian Anak Siklus I

\begin{tabular}{|c|c|c|c|}
\hline No & Skor & Kriteria & Persentase \\
\hline 1 & $>6$ & Baik & $60 \%$ (9 anak) \\
\hline 2 & $5-6$ & Cukup & $33.33 \%$ (5 anak) \\
\hline 3 & $<5$ & Kurang & $6.67 \%$ (1 anak) \\
\hline \multicolumn{3}{|c|}{ Jumlah } & $100 \%$ \\
\hline
\end{tabular}

Pada tabel 2 di atas dapat diketahui bahwa pada Siklus I anak yang memiliki perhatian pada kriteria perhatian baik mencapai $60 \%$ (9 anak), anak yang menunjukkan perhatian dengan kriteria perhatian cukup sebesar $33.33 \%$ (5 anak), dan anak yang memiliki perhatian dengan kriteria perhatian kurang sebesar $6.67 \%$ (1 anak). 


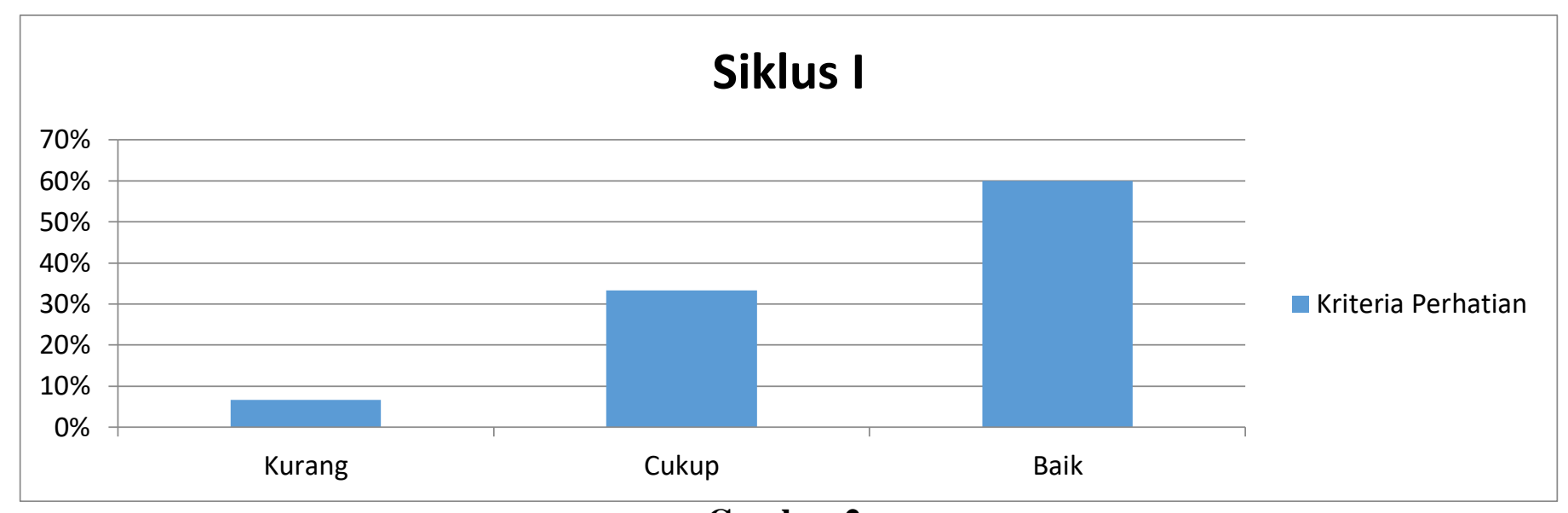

Gambar 2.

Grafik Persentase Perhatian Anak Siklus I

\section{Siklus II}

Pengamatan dilakukan bersamaan dengan berlangsungnya tindakan. Pengamatan yang dilakukan selama kegiatan bercerita meliputi:(1) konsentrasi,ingatan, dan (3) pemahaman. Berdasarkan pengamatan yang dilakukan pada Siklus II diperoleh rata-rata hasil yang dicapai selama tiga kali pertemuan dapat dilihat pada tabel di bawah ini:

Tabel 3.

Rekapitulasi Data Perhatian Anak Siklus II

\begin{tabular}{|c|c|c|c|}
\hline No & Skor & Kriteria & Presentase (\%) \\
\hline 1 & $>6$ & Baik & $93.33 \%$ (14 anak) \\
\hline 2 & $5-6$ & Cukup & $6.67 \%$ (1 anak) \\
\hline 3 & $<5$ & Kurang & $0 \%$ \\
\hline
\end{tabular}

Berdasarkan rata-rata hasil yang dicapai pada tindakan Siklus II, anak yang memiliki perhatian pada kriteria perhatian baik mencapai 93,33\% (14 anak), anak yang memiliki perhatian dengan kriteria perhatian cukup sebesar6,67 \% (1 anak), dan anak yang memiliki perhatian dengan kriteria perhatian kurang sebesar0 $\%$ (tidak ada). Data pada tabel hasil perhatian anak Siklus II dapat diperjelas melalui grafik dibawah ini.

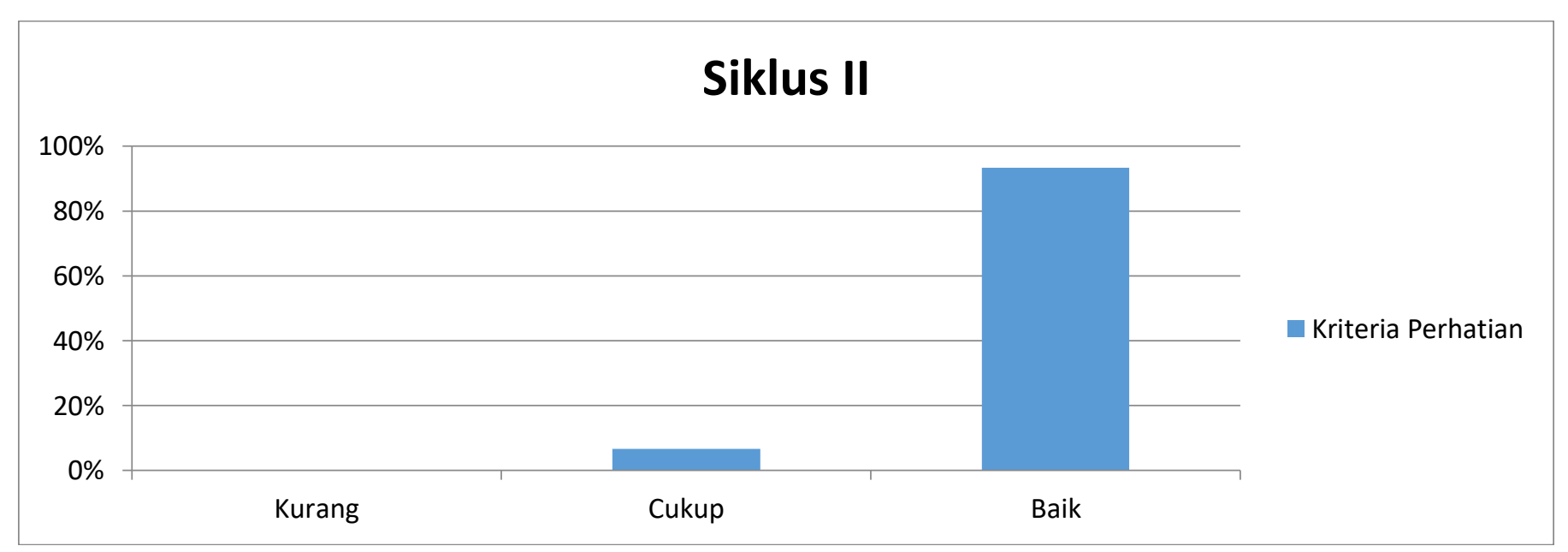

\section{Gambar 3. \\ Grafik Persentase Perhatian Anak Siklus II}

Setelah dilaksanakan tindakan pada siklus II maka dapat diketahui bahwa perhatian anak sudah mengalami peningkatan. Berdasarkan hasil yang diperoleh, anak yang menunjukkan perhatian dengan kriteria perhatian baik mencapai 93,33(14 anak), anak yang menunjukkan perhatian dengan kriteria 
perhatian cukup sebesar 6,67\% (1 anak), dan anak yang menunjukkan perhatian dengan kriteria perhatian kurang sebesar $0 \%$ (tidak ada).

Setelah dilakukan perbaikan akhirnya perhatian anak pada pembelajaran kegiatan bercerita dapat ditingkatkan melalui metode bercerita dengan media boneka tangan. Oleh karena itu upaya peningkatan perhatian tidak perlu dilakukan lagi karena telah mencapai indikator keberhasilan yang ditetapkan yaitu $80 \%$ dari jumlah anak menunjukkan perhatian pada kriteria baik.Berdasarkan paparan pada hasil penelitian dapat dilihat perbandingan perhatian anak pada pra tindakan, siklus I, dan siklus II. Adapun rekapitulasi hasil perhatian anak pra tindakan, siklus I, dan siklus II dapat dilihat pada Tabel berikut.

Tabel 4.

\section{Rekapitulasi Perbandingan Perhatian Anak Pra Tindakan, Siklus I, dan Siklus II}

\begin{tabular}{clccc}
\hline No & Kriteria & Pra Tindakan & Siklus I & Siklus II \\
\hline 1 & Baik & $13.33 \%(2$ anak $)$ & $60 \%(9$ anak $)$ & $93.33 \%(14$ anak $)$ \\
2 & Cukup & $20 \%(3$ anak $)$ & $33.33 \%(5$ anak $)$ & $6.67 \%(1$ anak $)$ \\
3 & Kurang & $66.67 \%(10 \mathrm{anak})$ & $6.67 \%(1 \mathrm{anak})$ & $0 \%$ (tidak ada) \\
\hline
\end{tabular}

Berdasarkan tabel di atas maka diketahui bahwa pada pra tindakan anak yang memiliki perhatian dengan kriteria perhatian baik hanya sebesar $13.33 \%$ (2 anak), anak yang memiliki perhatian dengan kriteria perhatian cukup sebesaar 20(3 anak), dan sisanya menunjukkan perhatian dengan kriteria perhatian kurang sebesar $66.67 \%$ (10 anak). Pada siklus I perhatian anak dengan kriteria perhatian baik meningkat menjadi $60 \%$ (9 anak), anak yang memiliki perhatian dengan kriteria perhatian cukup meningkat menjadi $33.33 \%$ (5 anak), dan anak yang memiliki perhatian dengan kriteria perhatian kurangberkurang menjadi $6.67 \%$ ( 1 anak). Selanjutnya pada siklus II anak yang menunjukkan perhatian dengan kriteria perhatian baik meningkat kembali menjadi $93.33 \%$ (14 anak), anak yang menunjukkan perhatian dengan kriteria perhatian cukup berkurang menjadi 6.67(1 anak), dan anak yang menunjukkan perhatian dengan kriteria perhatian kurang $0 \%$ (tidak ada). Data pada tabel rekapitulasi hasil perhatian anak pra tindakan, Siklus I, dan Siklus II dapat diperjelas melalui grafik berikutnya.

\section{Kriteria Perhatian}

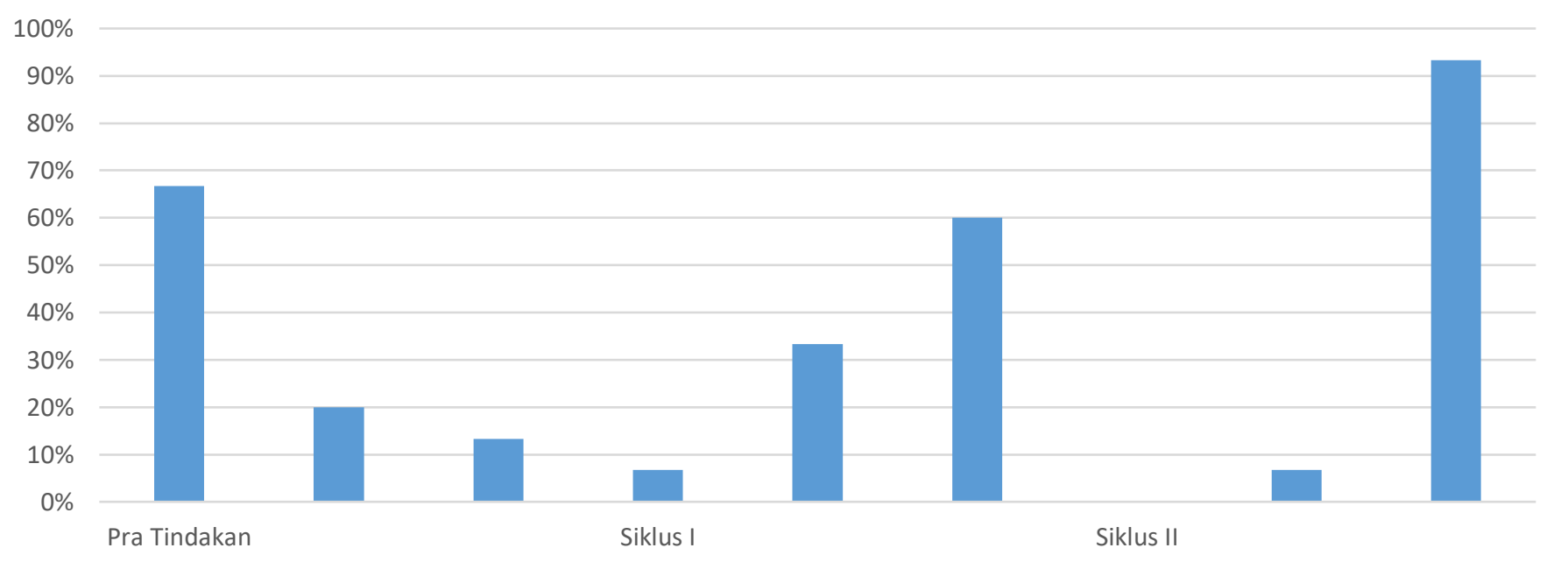

Gambar 4.

Grafik Persentase Perhatian Anak Pra Tindakan, Siklus I, Siklus II

Dalam penelitian ini perhatian anak Kelompok B TK Nurul Ibadah pada saat pembelajaran kegiatan bercerita belum optimal. Penyebab kurangnya perhatian anak pada saat pembelajaran kegiatan bercerita karena guru belum menggunakan media yang menarik pada saat bercerita. Untuk meningkatkan perhatian anak Kelompok B TK Nurul Ibadah peneliti menggunakan metode bercerita dengan media boneka tangan. 
Pada pra tindakan anak yang menunjukkan perhatian dengan kriteria baik hanya sebanyak 2 anak dari 15 anak di dalam kelas. Setelah dilakukan tindakan yaitu pada siklus I perhatian anak dengan kriteria baik meningkat menjadi 9 anak, namun hasil yang dicapai pada siklus I belum mencapai kriteria keberhasilan yang di tetapkan karena mengalami beberapa kendala antara lain: (1) media boneka tangan yang digunakan kurang besar sehingga anak yang jauh dari guru ingin mendekat, (2) media boneka tangan yang digunakan kurang bervariasi karena hanya terbatas pada dua tokoh, (3) pengaturan tempat duduk kurang nyaman, (4) masih banyak anak yang kurang antusias dalam menjawab pertanyaan. Berdasarkan hal tersebut, peneliti dan kolaborator sepakat untuk melanjutkan pada Siklus II dengan melakukan perbaikan-perbaikan terhadap kendala yang muncul pada tindakan siklus I. Pada siklus II ini perhatian anak pada kriteria perhatian baik meningkat kembali sebanyak 14 anak. Pada tahap ini juga masih ada 1 anak yang belum mencapai kriteria perhatian baik, hal ini dikarenakan anak tersebut kurang memiliki antusias saat mengikuti pembelajaran kegiatan bercerita dan sering terlihat melamun. Guru sudah melakukan upaya dengan lebih memotivasi anak dan memberikan reward namun anak tersebut masih belum bisa menunjukkan perhatian dengan kriteria baik.

Kegiatan bercerita dengan menggunakan media yang menarik merupakan stimulus yang kuat untuk menarik perhatian anak sehingga anak akan bersungguh-sungguh dalam memperhatikan guru pada saat bercerita. Perhatian anak yang baik ditunjukkan melalui konsentrasi yaitu mendengarkan cerita yang dibacakan gurusampai selesai,mampu mengingat nama-nama tokoh dalam cerita dan dapat menjawab pertanyaan dari guru.

Berdasarkan hasil penelitian yang telah diuraikan di atas, perhatian anak Kelompok B TK Nurul Ibadah pada saat proses pembelajaran kegiatan bercerita dapat ditingkatkan melalui penggunaan metode bercerita dengan media boneka tangan. Peningkatan perhatian anak juga tidak lepas persiapan pembelajaran bercerita yang lebih matang, keterampilan guru dalam bercerita dan penggunaan media yang baik.

\section{Simpulan}

Perhatian anak melalui metode bercerita dengan media boneka tangan dapat ditingkatkan melalui langkah-langkah sebagai berikut:(1) guru mengkondisikan anak, (2) guru memberitahu judul cerita yang akan dibacakan, (3)guru memperkenalkan boneka tangan sesuai tokoh dalam cerita, (4) guru menceritakan isi cerita, dan (5) pada bagian akhir guru memberikan pertanyaan kepada anak untuk mengetahui ingatan dan pemahaman anak terhadap cerita yang dibacakan. Selain itu pemberian reward bagi anak yang bisa menjawab pertanyaan dapat menambah motivasi anak.Peningkatan perhatian anak terjadi pada setiap pertemuan dari Pra Tindakan, Siklus I dan Siklus II. Pada pra tindakan perhatian anak dengan kriteria perhatian baik hanya sebesar $13.33 \%$ ( 2 anak), kemudian pada siklus I perhatian anak dengan kriteria perhatian baik mencapai 60\% (9 anak), dan pada siklus II meningkat kembali hingga mencapai 93.33\% (14 anak).

\section{DAFTAR PUSTAKA}

Abu Ahmadi, 2003. Psikologi Umum. Jakarta: Rineka Cipta.

Ahmad Rohani. 2004. Pengelolaan Pengajaran. Jakarta: Rineka Cipta.

Anas Sudjiono. 2008. Pengantar Statistika. Jakarta: Rajawali Press.

Azhar Arsyad. 1996. Media Pembelajaran. Jakarta: Grafindo.

Cucu Eliyawati. 2005. Pemilihan dan Pengembangan Sumber Belajar untukAnak Usia Dini. Jakarta: Depdiknas Dirjen Dikti. . 2006. Al-Quran dan Terjemahnya. Bandung: Departemen Agama RI.

Ebta Setiawan. (2012. Diakses dari http://kbbi.web.id/paham pada 30 Maret 2015.

Klara. (tt). Media Boneka Tangan Dapat Meningkatkan Keterampilan Bercerita.

Diakses dari http://eprints.uns.ac.id/11293/1/112-478-1-PB.pdf pada 29Januari 2015.

Moeslichatoen. (2004). Metode Pengajaran di Taman Kanak-Kanak. Yogyakarta: Rineka Cipta

Muhammad Fadlillah. 2014. Desain Pembelajaran PAUD. Yogyakarta: Ar Ruzz Media.

Muhammad Idrus. 2009. Metode Penelitian Sosial. Jakarta: Bumi Aksara.

Nini Subini. 2012. Psikologi Pembelajaran. Yogyakarta: Mentari Pustaka.

Nurul Zuriah. 2005. Metode Penelitian Sosial Dan Pendidikan. Jakarta: Bumi Aksara. 
Slameto. 2003. Belajar dan Faktor-Faktoryang Mempengaruhinya.Jakarta:Rineka Cipta.

Sofia Hartati. 2005. Perkembangan Belajar Pada Anak Usia Dini. Jakarta: Depdiknas Dirjen Dikti.

Suharsimi Arikunto. 2006. Penelitian Tindakan Kelas. Jakarta: Bumi Aksara. .2010. Manajemen Penelitian. Jakarta: Rineka Cipta.

Sumadi Suryabrata. 2004. Psikologi Pendidikan. Jakarta: Raja Grafindo Persada.

Syaiful Bahri Djamarah. 2005. Guru dan Anak Didik dalam Interaksi Edukatif. Jakarta: PT. Asdi Mahasatya

Syintha Yulia dkk. 2012. Penggunaan Alat Peraga Boneka Wayang Untuk Meningkatkan Kemampuan Bercerita Pada Anak Kelompok B TK Aisyiyah 56 Baron Tahun Ajaran 2011/2012. Diakses dari http://core.ac.uk/download/pdf//12349655.pdf pada 12 Februari 2015.

Tadkiroatun Musfiroh. (2005). Bercerita Untuk Anak Usia Dini. Jakarta: Depdiknas.

Trianto. (2011). Desain Pengembangan Pembelajaran Tematik. Jakarta: Kencana.

Undang-Undang No 20 Tahun 2003 Tentang Sisdiknas. Diakses dari http://www.unpad.ac.id/wpcontent/uploads/2012/10/UU20-2003-Sisdiknas.pdf. pada 2 Februari 2015. 